\title{
Toxic Discourse
}

\section{Citation}

Buell, Lawrence. 1998. Toxic Discourse. Critical Inquiry 24(3): 639-665.

\section{Published Version}

http://dx.doi.org/10.1086/448889

\section{Permanent link}

http://nrs.harvard.edu/urn-3:HUL.InstRepos:2637816

\section{Terms of Use}

This article was downloaded from Harvard University's DASH repository, and is made available under the terms and conditions applicable to Other Posted Material, as set forth at http:// nrs.harvard.edu/urn-3:HUL.InstRepos:dash.current.terms-of-use\#LAA

\section{Share Your Story}

The Harvard community has made this article openly available.

Please share how this access benefits you. Submit a story.

\section{Accessibility}




\section{Toxic Discourse}

\section{Lawrence Buell}

The fear of a poisoned world is being increasingly pressed, debated, debunked, and reiterated from many disciplinary vantage points: medicine, political science, history, sociology, economics, and ethics among others. Seldom however is toxicity discussed as a discourse. This essay aims to define the forms, origins, uses, and critical implications of toxic rhetoric, conceiving it as an interlocked set of topoi whose force derives partly from the exigencies of an anxiously industrializing culture, partly from deeperrooted Western attitudes. In order to make this analysis pointed and manageable, and not to outrun the limits of my knowledge, I shall focus on the United States, although many of my points apply to Anglophone settler cultures worldwide, if not also to other regions (and few remain untouched) influenced by Western environmental institutions.

As we shall see, toxic discourse challenges traditional understandings of what counts as an environmentalist movement or ethos. It calls for a new history of U.S. environmentalism that would place the wilderness preservationist John Muir and the urban social reformer Jane Addams in the same narrative. It insists on the interdependence of ecocentric and anthropocentric values. It underscores the point that environmentalism

Initial versions of portions of this essay were delivered as talks at Swarthmore College, the University of Oregon, the California Institute of Technology, and the 1996 Modern Language Association Convention. I am most grateful for valuable suggestions received on each occasion. My particular thanks to Daniel Kevles, Donald Swearer, Mark Wallace, Kevin Gilmartin, Cindy Weinstein, Bill Rossi, Louise Westling, William Howarth, Bill Brown, and Steve Holmes, my research assistant. 
must make concerns for human and social health more central and salient than it traditionally has if it is to thrive, perhaps even to survive. Partly in consequence, toxic discourse also calls for rethinking certain standard expectations normally brought to the work of critical reading. It unsettles received assumptions about the boundaries of nature writing and environmental representation generally; it provides a striking instance of the hermeneutics of empathy and suspicion as they are pitted against each other, and the potentially high stakes at issue in that conflict; and it reopens fundamental questions about both the cultural significance and the ethics of metaphor.

There seem to be at least two reasons why the discourse of toxicity has not been treated with the same attention as its chemical, medical, social, and legal aspects. One is surely the pragmatism that plays a major part in shaping all agendas of discussion. Discourse may seem a low priority when health or even property is jeopardized. Not even most humanistic intellectuals might agree with Emerson's dictum that the most abstract truth is the most practical. Also significant, though, has been the manner in which environmental issues have been framed by the likeliest potential contributors to the inquiry. Within literary and rhetorical studies, the impetus to engage environmental issues has mainly come from the so-called ecocritical movement, which to date has been energized by two chief ethico-political commitments: protection of the endangered natural world and recuperation of a sense of how human beings have been and might be imagined as (re)connected with it, notwithstanding the threat of the death of nature from industrialism and/or postmodernity. ${ }^{1}$ Ecocriticism's recency, together with its commitment to recuperation, have limited attention to toxicity per se. ${ }^{2}$ The other venue from which

1. A helpful conspectus, anthology, and annotated bibliography that may serve as a kind of interim report on ecocriticism's origins and early stages of unfolding is provided by The Ecocriticism Reader, ed. Cheryll Glotfelty and Harold Fromm (Athens, Ga., 1996).

2. Note, however, several contributions to Green Culture: Environmental Rhetoric in Contemporary America, ed. Carl G. Herndl and Stuart C. Brown (Madison, Wisc., 1996): M. Jimmie Killingsworth and Jacqueline S. Palmer, "Millennial Ecology: The Apocalyptic Narrative from Silent Spring to Global Warming," pp. 21-45; Steven B. Katz and Carolyn R. Miller, "The Low-Level Radioactive Waste Siting Controversy in North Carolina: Toward a Rhetorical Model of Risk Communication," pp. 111-40; and Craig Waddell, "Saving the Great Lakes: Public Participation in Environmental Policy," pp. 141-65. In rhetorical studies, see also Killingsworth and Palmer's previous work, Ecospeak: Rhetoric and Environmental

Lawrence Buell, the John P. Marquand Professor of English at Harvard University, is the author of New England Literary Culture (1986) and The Environmental Imagination: Thoreau, Nature Writing, and the Formation of American Culture (1995) among other works. His current projects include a book in progress entitled The Work of Imagination in an Endangered World. 
environmental issues have been most explored by those interested in discursive formations-cultural studies-has tended to epiphenomenalize the physical environment by conceiving it as social construct and thus as a symptomatic register of political or economic power, or as a site of cultural contestation. ${ }^{3}$ Thus ecocriticism has lacked epistemological and political sophistication, while cultural studies has been quick to deconstruct physical environment as mystification or political theater. But let me not sound ungrateful to either, who am greatly indebted to both, particularly the former, and should like to see a greater cross-fertilization between them. ${ }^{4}$ I hope this essay will show one way that this can usefully be done.

Although the threat of toxification has long been felt, not only since the industrial revolution but since late antiquity, ${ }^{5}$ in recent years the felt

Politics in America (Carbondale, Ill., 1992). In literary studies, compare my chapter on "Environmental Apocalypticism" in The Environmental Imagination: Thoreau, Nature Writing, and the Formation of American Culture (Cambridge, Mass., 1995), pp. 280-308.

3. For example, Fredric Jameson: "Pollution, although it's horrifying and dangerous, is maybe simply a spin-off of this new relationship to nature," that is, "the industrialization of agriculture and the transformation of peasants or farmers into agricultural workers" (Fredric Jameson, interview with Paik Nak-chung, in Global/Local: Cultural Production and the Transnational Imaginary, ed. Rob Wilson and Wimal Dissanayake [Durham, N.C., 1996], pp. 353, 352). See also Masao Miyoshi, "A Borderless World? From Colonialism to Transnationalism and the Decline of the Nation-State," Critical Inquiry 19 (Summer 1993): 746-48; rpt. in Global/Local, pp. 94-95. For Jameson the reductive "simply" reflects the belief "that ecological politics tends to be bourgeois politics" (p. 353)-questionable in light of recent events, I argue below. The most extended ecopolitical critiques from this basic perspective are Andrew Ross, Strange Weather: Culture, Science, and Technology in the Age of Limits (London, 1988) and The Chicago Gangster Theory of Life: Nature's Debt to Society (London, 1994).

4. Buell, The Environmental Imagination, pp. 83-114, attempts to bridge textuality theory and (a revised version of) representational realism from the side of ecocriticism, arguing that the vision of text as disjoined from world needs to be complemented by the vision of text's capacity to reconnect with world, and that the vision of nature as socially constructed needs to be counterpoised by the vision of humans and societies as themselves in considerable measure constructed by physical environment. Another kind of bridging effort is $\mathrm{N}$. Katherine Hayles's coordination of (scientific) realism and social constructionism in her theory of "constrained constructivism"; see, for example, "Constrained Constructivism: Locating Scientific Inquiry in the Theater of Representation," in Realism and Representation: Essays on the Problem of Realism in Relation to Science, Literature, and Culture, ed. George Levine (Madison, Wisc., 1993), pp. 27-43; "Searching for Common Ground," in Reinventing Nature? Responses to Postmodern Deconstruction, ed. Michael E. Soulé and Gary Lease (Washington, D.C., 1995), pp. 47-63; and "Simulated Nature and Natural Simulations: Rethinking the Relation between the Beholder and the World," in Uncommon Ground: Toward Reinventing Nature, ed. William Cronon (New York, 1995), pp. 409-25.

5. See, for example, J. Donald Hughes's chapter "Industrial Technology and Environmental Damage" in his Pan's Travail: Environmental Problems of the Ancient Greeks and Romans (Baltimore, 1994), pp. 112-28. 
urgency has become far more widespread. Love Canal, Three Mile Island, Bhopal, Chernobyl, the Exxon Valdez: this modern mantra lists both actual incidents and their subsequent history in the postindustrial imagination that have ensured that the environmental apocalypticism triggered by Hiroshima and Nagasaki would outlast the cold war. Even the world's privileged enclaves manifest symptoms of what social theorist Ulrich Beck has called "the risk society": a condition of "immiseration" characterized by a "solidarity from anxiety" deriving from the inabilityeven with science's assistance-to calculate the lethal consequences of everyday life.$^{6}$ Concurrently, an awakened toxic consciousness and green activism have increased dramatically among the nonprivileged. In the United States, the antitoxics campaign has changed the face of environmentalism since its inception as a large-scale movement in the wake of the Love Canal controversy in the late $1970 \mathrm{~s},{ }^{7}$ broadening from a relatively few local suburban disturbances to a national network of some five thousand community groups.

Whereas preservationist agendas advocated by mainstream environmental groups have been financially supported, and their organizations staffed, by well-educated middle-class whites (most often male), the environmental justice $(\mathrm{EJ})$ movement (for which the campaigns against toxic dumping have been the catalyst and remain the centerpiece) has increasingly been led by nonelites, more often than not women, and includes a strong minority presence ${ }^{8}$ - and understandably so, given where waste

6. Ulrich Beck, Risk Society: Towards a New Modermity, trans. Mark Ritter (1986; London, 1992), pp. 51, 49; see also pp. 19-84. Compare Beck's collection of essays, Ecological Enlightenment: Essays on the Politics of the Risk Society, trans. Ritter (1991; Atlantic Highlands, N.J., 1995) and "World Risk Society as Cosmopolitan Society? Ecological Questions in a Framework of Manufactured Uncertainties," Theory, Culture, and Society 13 (Nov. 1996): 1-32. Likewise, Kai Erikson, "A New Species of Trouble," in Communities at Risk: Collective Responses to Technological Hazards, ed. Stephen Robert Couch and J. Stephen Kroll-Smith (New York, 1991), argues that "toxic emergencies really are different" from all precursor threats in the kind of "dread" they induce, since "they have no [distinct] frame" (temporally or spatially), they are invisible, there is no secure sanctuary, and they surpass the capacity of science to specify physical, let alone emotional, risk (pp. 17, 18). The difference in ideological valence between these two accounts is notable: Erikson's is a more or less politically neutral sociological overview, while Beck's is explicitly anti-industry, diagnosing toxic threat/fear as "the embodiment of the errors of a whole epoch of industrialism," "a kind of collective return of the repressed" (Beck, "World Risk Society as Cosmopolitan Society?" p. 24).

7. Love Canal was a lower-middle-class subdivision of Niagara Falls, N.Y., built upon a former waste dump created by the Hooker Chemical Company, a subsidiary of Occidental Petroleum. Advocates for residents claimed that they had experienced abnormal rates of birth defects and environmentally induced illness. The most recent among numerous studies, which places special emphasis on the discrepancy among different interest groups' accounts, is Allan Mazur, Love Canal (Cambridge, Mass., 1997).

8. Robert Gottlieb, Forcing the Spring: The Transformation of the American Environmental Movement (Washington, D.C., 1993), chaps. 5-8 and conclusion, is the best overview to date of grassroots antitoxics activism and the demographic diversification of this movement relative to mainstream environmentalism. 
dumps and other pollution sources are typically located: "all Americans [are] not ... being poisoned equally." Nor have these nontraditional activists greatly cared to identify with mainstream preservationists; on the contrary, they have been as likely as not to disparage them as "bird kissers and tree huggers." ${ }^{10}$ "In their previous lives," notes one account of the early leaders, "each of these folks had led overwhelmingly private lives filled with private, immediate concerns. They did not bother themselves with 'political' matters.... None of them was eager to get involved. At most, one hears them speak of doing it reluctantly, out of a sense of duty, because someone had to. Then, disillusioned and angered by their experiences, each moved toward a radical critique of society, business, and government." 11

The 1990s may be witnessing a trend toward ecojustice activism building bridges with traditional environmentalist causes. For instance, the first two of the seventeen points in the 1991 manifesto emanating from the First National People of Color Environmental Leadership Summit in Washington, D.C., were (1) "Environmental Justice affirms the sacredness of Mother Earth, ecological unity and the interdependence of all species, and the right to be free from ecological destruction"; and (2) "Environmental Justice demands that public policy be based on mutual respect and justice, for all peoples, free from any form of discrimination or bias." 12 These declarations strive for an eclectic blend of old-time American democratic civil religion, 1960s-era civil rights guarantees, Native American spirituality, and preservationist ethics. But what most seems to distinguish contemporary ecopopulism is the activism of nonelites, the emphasis on community, and the reconception of environmentalism as an instrument of social justice.

Even if the theory of environmental justice proves too idealistic or partisan for most legislators to endorse, the fear of environmental poison-

9. Mark Dowie, Losing Ground: American Environmentalism at the Close of the Twentieth Century (Cambridge, Mass., 1995), p. 141. 1993): 7.

10. Richard Regan, "Environmental Equity: Risk and Race," The Egg 13 (Spring

11. Andrew Szasz, Ecopopulism: Toxic Waste and the Movement for Environmental Justice (Minneapolis, 1994), p. 97; hereafter abbreviated $E c$. Although the quoted statements are broadly applicable, Ecopopulism fails at some points to distinguish between suburban ecopopulist activism by middle-class whites and the activism of communities of poor whites and/or people of color, where the levels of initial domestic tranquility and naïve civic trust were by no means so high. Of the latter, especially, it could not be claimed that before their environmental awakening "they pretty much believed in a textbook image of government; they trusted that officials do their jobs honestly and well" (p. 97). Andrew Hurley, Environmental Inequalities: Class, Race, and Industrial Pollution in Gary, Indiana, 1945-1980 (Chapel Hill, N.C., 1995 ) is a splendid case study that differentiates the underlying political orientations and specific environmentalist priorities of Gary's middle-class whites, working-class whites, and African Americans.

12. "Principles of Environmental Justice," Race, Poverty, and the Environment 2 (Fall 1991-Winter 1992): 32. 
ing that energizes it will likely have at least as good a chance of remaining a compelling public issue as nuclear fear during the cold war era, especially given the certainty of future, highly publicized emergencies with potentially serious consequences for public health. For the iconographic power of toxic discourse as refracted through the media has been crucial to the quickening of the " scissor' effect" of tightened legal regulations on dumping plus local blocking of new waste sites, producing "'voluntary" moves on industry's part to reduce waste production $(E c$, p. 145$) .{ }^{13}$ Of course one of those voluntary moves has been to move industry offshore-maquiladoras along the U.S.-Mexican border, sweatshops in Latin America and southeast Asia, garbage flotillas to Africa-thereby aggravating the problem of eco-inequality on a global scale and approaching, it would seem, the dystopian end point of modernization envisaged by Henri Lefebvre: the whole earth reorganized under the aegis of "the capitalist "trinity" (land-capital-labor) into an "abstract space" at once fragmented and hierarchical. ${ }^{14}$ But that global metastasis confirms the potency of toxic discourse itself (which Lefebvre's anxieties about runaway modernism anticipate), ${ }^{15}$ as does the rhetoric, if not the daily behavior, of national leaders and citizenry alike. President Clinton's August 1996 nomination acceptance speech proclaimed as a self-evident, shameful truth that ten million U.S. children under twelve live three miles from a toxic waste dump. At the popular level, recent public opinion surveys, like the Kempton, Bolster, and Hartley survey (1995) of a cross-section of five different groups of West Coasters (Earth First!-ers, Sierra Clubbers, dry cleaners, laid-off sawmill workers, and a random sample of Californians) show a strong consensus for such propositions as "a healthy envi-

13. Lee Clarke, "Political Ecology of Local Protest Groups," in Communities at Risk, in regards to Love Canal vs. Binghamton, observes that "national media coverage is necessary, if not sufficient, before grass roots associations can gain enough power to become real forces as protest associations" (pp. 103-4) - a view that seems almost universally accepted. "Thoreau and Gandhi," chuckles Beck, "would have beamed with delight to see Greenpeace using the methods of the media age to stage world-wide civil resistance" (Beck, "World Risk Society as Cosmopolitan Society?" p. 23). Chapter 7 of Clarke's monograph on the Binghamton case, Acceptable Risk? Making Decisions in a Toxic Environment (Berkeley, 1989), notes the problems of ineffective coordination between movement and media.

14. Henri Lefebvre, The Production of Space, trans. Donald Nicholson-Smith (1974; Oxford, 1991), p. 282.

15. In "Multinational Corporations and the Global Environment," a careful, hardheaded analysis, Nazli Choucri finds no corporate paragons of environmentalist selfrestraint but also no countries that could be called extreme "'pollution havens"' either, and identifies a series of checks upon exploitative behavior that seem to be starting to take effect, such as a worldwide movement toward restrictive environmental legislation and "increased acceptance of the "polluter pays principle'. . . in international forums" (Nazli Choucri, "Multinational Corporations and the Global Environment," Global Accord: Environmental Challenges and International Responses, ed. Choucri [Cambridge, Mass., 1993], pp. 211, 249). 
ronment is necessary for a healthy economy." ${ }^{16}$ In the developing world, to an even greater degree, threat to human life and well-being offers a more cogent basis for global accord on environment as a priority than does traditional preservationism. ${ }^{17}$

Contemporary toxic discourse effectively starts with Rachel Carson's Silent Spring (1962), whose opening chapter, "A Fable for Tomorrow," introduces one of the key discursive motifs: a "town in the heart of America" that awakes to a birdless, budless spring. "This town does not actually exist," Carson concludes, "but it might easily have a thousand counterparts in America or elsewhere in the world," for "a grim specter has crept upon us almost unnoticed, and this imagined tragedy may easily become a stark reality we all shall know." ${ }^{18}$ She then launches into an indictment of DDT in particular and chemical pesticides in general.

Media coverage of Love Canal drew on similar images of community disruption, "showing visuals that seemed to signify 'normalcy,' but [that revealed] the opposite, through voice-over narration. . . . A boy bicycles along a quiet suburban street while the narrator says, 'There have been

16. Willett Kempton, James S. Boster, and Jennifer A. Hartley, Environmental Values in American Culture (Cambridge, Mass., 1995), p. 259. The percentages responding positively were, respectively, $94,82,97,82$, and 77 . It is less clear how well environmental concern stacks up against other public priorities. A December 1996 Wall Street Journal/NBC News survey of two thousand U.S. citizens found, for example, that "protecting the environment" ranked thirteenth out of a possible fourteen on the citizens' "top priority for Congress" list (at 26 percent), against the top vote-getters of "improving public education" and "reducing crime" (both 57 percent), although 81 percent of respondents rated the "environmental movement" as having had a "positive impact" on "today's values," as against the only 13 percent who dissented (Albert R. Hunt et al., "What Do We Want?" Wall Street Journal, 13 Dec. 1996, pp. R1, R4).

17. For a thoughtful critique of the limits of traditional first-world green humanistic thinking along these lines, see, for example, Ramachandra Guha, "Radical American Environmentalism and Wilderness Preservation: A Third World Critique," Environmental Ethics 11 (Spring 1989): 71-83. An obvious case in point would be the 1987 Montreal protocols and subsequent ozone accords, arguably "the first truly global treaty that offers protection to every single human being on this planet," and "unique because it seeks to anticipate and manage a world problem before it becomes an irreversible crisis" (Mustafa Tolba, head of the United Nations Environmental Program, quoted in Karen T. Litfin, Ozone Discourses: Science and Politics in Global Environmental Cooperation [New York, 1994], p. 115).

18. Rachel Carson, Silent Spring (New York, 1962), pp. 13, 14-15; hereafter abbreviated SS. The "epochal" impact of this book and the controversy provoked by it in stimulating contemporary environmentalism generally and antitoxics agitation particularly seems widely accepted (Gottlieb, Forcing the Spring, p. 81), even though the actual success of Carson's campaign against chemical pesticides remains debatable, and, as noted below, toxic fear was invoked rather than invented by Carson. 
instances of birth defects and miscarriages among families.' . . The most frequent, most persistent images throughout these news stories," this same analysis continues, "were of community lands (school yard, suburban field, backyards) that ought to be green, vibrant with suburban/ domesticated vegetation, but instead show only sparse, half-dead plant cover, punctuated with holes filled with unnatural-looking chemical soup; house yards and basements invaded by chemical ooze; disrupted neighborhood life" ( $E c$, pp. 43,44$)$. No less striking than how these images echo Silent Spring is their congruence with residents' life narratives. For instance Lois Gibbs, Love Canal's leading activist, insisted that when she arrived in 1972 she "didn't even know Love Canal was there. It was a lovely neighborhood in a quiet residential area, with lots of trees and lots of children outside playing. It seemed just the place for our family." Her awakening was slow and her sense of betrayal no less categorical than her former state of innocence. Returning one night from a Homeowners Association meeting, she was stunned when a companion remarked "that you could close your eyes and walk down the street and tell where every single storm sewer opening was just from the smell. It was true; even though I was in the midst of it, I still couldn't believe the contamination had reached my house." ${ }^{19}$ Studies of other "contaminated communities" report a similar picture: an awakening - sometimes slow and reluctantand a horrified realization that there is no protective environmental blanket, leaving one feeling dreadfully wronged-after which follows a gamut of possible reactions, such as outrage, acquiescence, impotence, denial, desperation..$^{20}$

These documents raise insoluble chicken-and-egg questions about what's constructing what. To what extent did media coverage of Love Canal shape Gibbs's autobiography? Or did residents' testimony shape the media coverage? To what extent were both preshaped by Silent Spring and its aftermath? Whatever one's answers, the testimony of Carson, Gibbs, and others clearly evince much older patterns of thought. In American literature, one finds anticipations of Carson more than a century ago. In Nathaniel Hawthorne's tale "Rappaccini's Daughter," for instance, the protagonist falls in love with a beautiful young woman who tends a strange botanical garden that turns out to be an anti-Eden of poisonous plants that her mad scientist father has created. Indeed, Beatrice herself is toxic, and the price Giovanni must pay if she is to be his

19. Lois Marie Gibbs, as told to Murray Levine, Love Canal: My Story (Albany, N.Y., 1982), p. 40; hereafter abbreviated $L C$.

20. For example, see Michael R. Edelstein, Contaminated Communities: The Social and Psychological Impacts of Residential Toxic Exposure (Boulder, Colo., 1988), pp. 11-12, 57. For comparable workplace reactions, see also Dorothy Nelkin and Michael S. Brown, Workers at Risk: Voices from the Workplace (Chicago, 1984), pp. 40-41, 71, 159. 
is to accept his own toxification and turn into a creature whose breath kills ordinary flies and spiders. The setting is medieval, but the scenario invites the same techno-dystopian rereading that Hawthorne himself performs on Pilgrim's Progress in "The Celestial Rail-road."21 Victorian era "sanitarian" exposés like Catherine Beecher's "The American People Starved and Poisoned" argue explicitly what Hawthorne suggests obliquely: that what we believe to be snug bastions of bourgeois domesticity are suffused with noxious lethal vapors. ${ }^{22}$

Both Carson and her populist successors, in short, revive a longstanding mythography of betrayed Edens, the American dispensation of which is traced by Leo Marx. For Marx, traditional mainstream American culture was marked by a naïve doublethink that allayed incipient anxieties about the techno-economic progress to which national policy has always been committed with escapist fantasies of inexhaustible natural beauty. This naïveté was critiqued by a handful of independently minded, creative thinkers like Thoreau and Melville who recognized the inherent contradiction between techno-boosterism and Currier-and-Ives identifcation of U.S. culture and folkways with pastoral landscapes. Marx terms the predominant mentality "simple pastoral," the contrarian vision of awakened intellectuals "complex pastoral." 23

It comes as no surprise, therefore, to find contemporary toxic discourse retelling narratives of rude awakening from simple pastoral to complex. As historians of architecture and city planning have shown, the cultural construction of suburbia in the U.S. and often even of urban neighborhoods as well has drawn heavily upon pastoral imagery and values: envisioning safe and clean communities, ample residential and public spaces (including, for suburbs, green oases of lawn around singlefamily homes and, for cities, emerald necklaces, garden parks, and apartment windowboxes). ${ }^{24}$ Intensifying traumas of pastoral disruption is the

21. See Nathaniel Hawthorne, "Rappaccini’s Daughter" and "The Celestial Rail-road," Mosses from an Old Manse, vol. 10 of The Centenary Edition of the Works of Nathaniel Hawthorme, ed. William Charvat et al., 20 vols. (Columbus, Ohio, 1962- ), pp. 91-128, 186-206.

22. See Catherine Beecher, "The American People Starved and Poisoned," Harper's New Monthly Magazine 33 (1866): 762-72. For the historical context, see John Duffy, The Sanitarians: A History of American Public Health (Urbana, Ill., 1990), pp. 93-134.

23. See Leo Marx, The Machine in the Garden: Technology and the Pastoral Ideal in American Culture (New York, 1964).

24. For suburbanization, see especially Peter G. Rowe, Making a Middle Landscape (Cambridge, Mass., 1991); for cities, see especially James L. Machor, Pastoral Cities: Urban Ideals and the Symbolic Landscape of America (Madison, Wisc., 1987). Robert Fishman, Urban Utopias in the Twentieth Century: Ebenezer Howard, Frank Lloyd Wright, and Le Corbusier (Cambridge, Mass., 1982), and Witold Rybczynski, City Life: Urban Expectations in a New World (New York, 1995) are testimony to the transnational force and durability of urban pastoral as a model, nuanced at least in principle according to the culture in question, for thinking about how cities should be designed, if not as a template for actual city planning. 
tendency for people to "have a strong but unjustified sense of subjective immunity" about domains familiar to them; hence, they fail to read product labels or to take elementary precautions when spraying in their homes or gardens. ${ }^{25}$

It was through the rose-colored lens of pastoral-utopian innocence that Lois Gibbs first saw the extremely modest residential subdivision of Love Canal. So too had residents first seen the landfill-plagued north Jersey community of Legler, where people had settled to "escape from the city to a rural idyll"; ${ }^{26}$ so too was Sumter County, Alabama, an impoverished, 70 percent African American district targeted by the EPA for one of the nation's largest waste disposal facilities, proclaimed by the head of local activist resistance as "a beautiful agricultural region." ${ }^{27}$ Just how accurate these images are is impossible to judge; very likely they are not, being ex post facto polemical depositions. But the facticity of the image matters less than its psychological and rhetorical potency.

In linking ecopopulist protest to pastoral oppositionalism, one risks blurring categories because traditional pastoralism's most conspicuous environmentalist legacy, the preservationism of the kind practised by Thoreau and Muir, was to become the operating philosophy of the elite environmental organizations against which environmental justice activism has defined itself. Not only does the latter have a different demographic mix, it also is, at its core, anthropocentric rather than ecocentric; that is, it is focused more on populated areas than open space and on community betterment rather than alone-with-nature experiences. Yet ecopopulism shares with preservationism the conviction that the biological environment ought to be more pristine than it is, ought to be a healthy, soul-nurturing habitat. So it makes sense for toxic discourse to enlist pastoral support. It inverts and democratizes the pastoral ideal: a nurturing space of clean air, clean water, and pleasant uncluttered surroundings that is ours by right.

Disenchantment from the illusion of the green oasis is accompanied or precipitated by totalizing images of a world without refuge from toxic penetration. This sense of entrapment forms a second topos propagated by Silent Spring. Carson repeatedly insists that "for the first time in the history of the world, every human being is now subjected to contact with dangerous chemicals, from the moment of conception until death" (SS, p. 24). The spectacle of communities, population groups, and finally the whole earth contaminated by occult toxic networks has been invoked by environmental justice activists in numerous ways. It has furthered the effort to create a sense of community of the disempowered: "From the

25. Mary Douglas, Risk Acceptability According to the Social Sciences (New York, 1985), p. 29 .

26. Edelstein, Contaminated Communities, p. 55.

27. Kaye Kiker, "The Nation's Dumping Ground," The Egg 10 (Summer 1990): 17. 
time oil is taken out of the ground in Alaska in the land of the Gwichen to the refining process in North Richmond [California] to the final combustion of the oil on the freeways through West Oakland, poor people and people of color pay the cost." ${ }^{28}$ It has helped mobilize groups of previously apolitical women, by underscoring "connections between particular health problems in their own lives and the larger world of public policies and power that cause them." ${ }^{29}$ It has been invoked by minority neighborhoods disproportionately threatened by hazardous waste facility sites to persuade white residents in contiguous districts that "no part of a community is an island unto itself; all residents benefit or suffer when any of them do." ${ }^{30}$ Not for nothing was the publication of the national organization of antitoxic resistance movements baptized Everyone's Backyard.

As with the rhetoric of pastoral betrayal, that of toxic interpenetration hardly originated with Carson, nor has it been confined to the Environmental Justice movement. It has pervaded popular culture via, for example, ecocatastrophe novels like Philip K. Dick's Do Androids Dream of Electric Sheep?, John Brunner's The Sheep Look Up, Scott Sanders's Terrarium, and Paul Theroux's $O$-Zone. ${ }^{31}$ Their impetus devolves, just as Carson's diagnostic does, from cold war era nuclear fear. Just before Silent Spring was published, President John F. Kennedy, who supported Carson's campaign to restrict use of chemical pesticides, warned the United Nations that "every inhabitant of this planet must contemplate the day when this planet may no longer be habitable." ${ }^{32}$ Carson explicitly played on such anxieties by branding the pesticides industry "a child of the Second World War" and by representing pesticides' consequences with the imag-

28. Lily Lee, "Energy and Air Pollution Are Social Issues," Race, Poverty, and the Environment 22 (Summer 1991): 1, 18.

29. Celene Krauss, "Blue-Collar Women and Toxic-Waste Protests: The Process of Politicization," Toxic Struggles: The Theory and Practice of Environmental Justice, ed. Richard Hofrichter (Philadelphia, 1993), p. 109.

30. Robert W. Collin and William Harris, Sr., "Race and Waste in Two Virginia Communities," Confronting Environmental Racism: Voices from the Grassroots, ed. Robert D. Bullard (Boston, 1993), p. 100.

31. Disasters, of which ecocatastrophe is one form, is one of the fifty genres identified in Science Fiction A to Z: A Dictionary of the Great S. F. Themes, ed. Isaac Asimov, Martin H. Greenberg, and Charles G. Waugh (Boston, 1982). Cynthia Deitering, "The Postnatural Novel: Toxic Consciousness in Fiction of the 1980s," in The Ecocriticism Reader, pp. 196-203, a short discussion of selected toxic dystopian fiction, makes clear that sci-fi and representational realism are interpenetrating categories.

32. Quoted in Spencer R. Weart, Nuclear Fear: A History of Images (Cambridge, Mass., 1988), p. 215. Weart treats ecocatastrophical fear as an offshoot of nuclear fear. I am also indebted to Thomas Schaub's analysis of Carson as a self-conscious intervener in cold war debates by turning right-wing tropes back upon themselves; see Thomas Schaub, "Rachel Carson and the Cold War," paper delivered at the American Studies Association Convention, 3 Nov. 1996. 
ery of war: weaponry, carnage, victimage, extermination, corpses, massacre, conquest (SS, p. 24). ${ }^{33}$

But theories that locate the origin of global toxification rhetoric in the cold war or nuclear era cannot account for the age and complexity of the rhetoric. Malthusian anxiety over the world's resources being ruined by overexploitation is not a new paradigm ${ }^{34}$ but rather a long tradition in conservationist thought. ${ }^{35}$ In the 1930 s and 1940s, artistconservationist J. N. "Ding" Darling popularized the vision of an alreadydepleted world in syndicated cartoons depicting the earth as a globe with a vast crater where the U.S. once was (to satirize corporate rapacity) or a tiny, near-empty kettle tended by a diminutive Mother Nature overshadowed by a monster in a loincloth (World Population) impatiently holding out a huge begging bowl. ${ }^{36}$ Indeed, the ruined-world image dates back to the first "modern" conservationist treatise, George Perkins Marsh's Man and Nature (1864), which in turn echoes warnings by European civil servants outposted during the seventeenth and eighteenth centuries on ecologically fragile island enclaves like St. Helena and Mauritius. ${ }^{37}$

When Richard Hatcher, the first African American mayor of Gary, Indiana, an adroit politician with a keen sense of social justice, managed to rally African Americans, middle-class suburbanites, and working-class whites behind a campaign for better air quality, it is not clear whether he or they were consciously influenced by Carson, much less by antecedent traditions of toxic discourse. But the success of Gary's environmental co-

33. Compare Ralph H. Lutts, "Chemical Fallout: Rachel Carson's Silent Spring, Radioactive Fallout, and the Environmental Movement," Environmental Review 9 (Fall 1985): 211-25.

34. As in John McCormick, Reclaiming Paradise: The Global Environmental Movement (Bloomington, Ind., 1989), pp. 191-96.

35. The 1972 Club of Rome report prepared by Donella H. Meadows et al., The Limits to Growth: A Report for the Club of Rome's Project on the Predicament of Mankind (New York, 1972), may be said to have reauthenticated the theme of scarcity as a central premise of contemporary environmentalism. William Ophuls, Ecology and the Politics of Scarcity: Prologue to a Political Theory of the Steady State (San Francisco, 1977), is one exemplary result, influential in its own right. In Meadows at al., Beyond the Limits: Confronting Global Collapse, Envisioning a Sustainable Future (Post Mills, Vt., 1992), the authors have both qualified and reaffirmed their previous position. In diagnosing depletion-anxiety as a rhetorical formation, I would not go so far as Ross, in The Chicago Gangster Theory of Life and recent conference papers, who debunks scarcity as a myth perpetrated by multinational corporate interest in inequitable resource distribution. Although the "Western"- or "north"-dominated economic oligopolies do simultaneously create surpluses of wealth and of poverty, the causes of depletion-anxiety seem more complicated and the anxiety itself, however sometimes manipulated, hardly without foundation.

36. Reproduced in David L. Lendt, Ding: The Life of Jay Norwood Darling (Ames, Iowa, 1989), unpaginated illustrations (dated 1938 and 1947) between pp. 54-55.

37. See especially Richard H. Grove, Green Imperialism: Colonial Expansion, Tropical Island Edens, and the Origins of Environmentalism, 1600-1860 (Cambridge, 1995). Still remoter antecedents lie in both Christian apocalyptic (particularly the Revelation of St. John) and classical writings (particularly the close of Lucretius, De Rerum Naturae). 
alition-until rust-belt recession hit the city so hard in the 1970s that unemployment overwhelmed other civic concerns-depended upon pollution's power as a social unifier: "one of the few issues that could bridge the divide between hostile social factions." ${ }^{38}$ As Ulrich Beck has written, whereas "poverty is hierarchic, smog is democratic." 39

No less crucial to the success of Hatcher's coalition building was his strategy of channelling communal hostility by linking environmental reform with social justice against "the common enemy" of corporate greed. ${ }^{40}$ This is a third major constituent of toxic discourse: the moral passion of a battle between David and Goliath. The motif has a dual provenance in U.S. environmentalist thought. The canonical inception point is the struggle between John Muir and Gifford Pinchot for the soul of Theodore Roosevelt over the question of whether to retain the Hetch Hetchy Valley as part of Yosemite National Park or to allow the valley to be dammed in order to bolster the San Francisco area's water supply. Muir, to no avail, accused "mischief-makers and robbers of every degree" of "trying to make everything dollarable," although he did manage to unsettle Roosevelt temporarily. ${ }^{41}$ Historically simultaneous with Muir's campaign, but rarely mentioned in histories of American environmentalism, ${ }^{42}$ was Upton Sinclair's The Jungle (1906), a landmark muckraking novel that exposed the victimization of workers in the meat-packing industry. This is the other provenance: not muckraking narrative alone but a congeries of initiatives on behalf of urban and workplace reform that began to gather momentum at the end of the nineteenth century, including the Ruskin-inspired settlement house movement, intensified labor agitation, and the birth of industrial toxicology. That the two legacies were not sooner linked suggests not simply a social compartmentalization by class but compartmentalization of space (workplace versus home and leisure spaces, town versus country). Hatcher interwove these concerns by proclaiming the common victimhood of all Gary's neighborhoods.

Carson, too, broke down these compartmentalizations, at the global level, thus ensuring that Silent Spring would become an inspiration for the Environmental Justice movement. In a commemorative essay, EJ activist Victor Lewis praised its exposé of "the demented love affair of corporate

38. Hurley, Environmental Inequalities, p. 140.

39. Beck, Risk Society, p. 36.

40. Hurley, Environmental Inequalities, p. 112.

41. Muir, "The Tuolumne Yosemite in Danger," Outlook, 2 Nov. 1907, p. 48; quoted by Stephen Fox, John Muir and His Legacy: The American Conservation Movement (Madison, Wisc., 1985), p. 141, which then provides a concise summary of issues, players, and events. For a more extended discussion, which itself has helped make this episode a canonical chapter in U.S. environmental historiography, see Roderick Nash, Wilderness and the American Mind, 3d ed. (New Haven, Conn., 1967), pp. 161-81.

42. Gottlieb, Forcing the Spring, p. 65, is exceptional. Daniel Kevles's history in progress of American environmentalism, a portion of which he has kindly shared with me, promises to carry Gottlieb's needed revision further. 
power with the chemical insect controls" and its protofeminist "denunciation of the outrages of patriarchy." 43 This in recognition of Carson's indictment of military and government agencies as well as chemical companies for hyperfocusing on eradication programs that didn't work and for dispensing poisons without reckoning consequences or warning of known risks.

Carson's own ire was less directed against specific organizations and officials, however, than against entrenched recalcitrance: against the "chemical barrage ... hurled against the fabric of life," "as crude a weapon as the cave man's club"; against the "tendency to brand as fanatics or cultists all who are so perverse as to demand that their food be free of insect poisons" (SS, pp. 261, 161). The invective gains force by not limiting itself to a single adversary. It carefully preserves an us-versus-them dichotomy without absolving the people for their acquiescence and complicity as chemical consumers-even as Silent Spring makes clear that ordinary citizens are victims of military, corporate, and government arrogance (with the opposition carefully masculinized). This universalizing turn within the rhetoric of blame is almost as important as the accusation itself. Even Lewis, who wishes Carson had pressed "the connections between social and environmental justice, between civil and environmental rights," refers to "our rampant misuse of agricultural pesticides." ${ }^{44}$ After all, the EJ activist must guard against insouciance or ignorance, even after having been "awakened," as well as against extrinsic evil. Significantly, Lewis's tribute to Carson is preceded by a hard-hitting, how-to article on "The DOs and DON'Ts of Fighting Pesticides," whose final warning is "DON'T hire a professional and go to sleep." ${ }^{45}$ Besides, in many contexts it is not only more accurate but also more effective to identify environmental racism as the culprit, rather than a particular agent.

In either case, the threat of infringement is fundamental to toxic discourse. The chief tactic of the EJ movement has been to promote a self-conscious, informed sense of local self-identification, victimhood, and grassroots resistance encapsulated by the image of "communities" or "neighborhoods" nationwide combatting "unwanted industrial encroachment and outside penetration." ${ }^{66}$ These terms imply population groups

43. Victor Lewis, "Rachel Carson Remembered," Race, Poverty, and the Environment 2 (Spring 1991): 5. The feminist implications of Carson's critique are developed especially in H. Patricia Hynes, The Recurring Silent Spring (New York, 1989), a study somewhat skewed by Hynes's special interest in the issue of reproductive rights, yet incisive and significant in placing Carson's life and legacy in the context of women's achievement in science and their victimage by patriarchally controlled technology.

44. Lewis, "Rachel Carson Remembered," pp. 18, 5.

45. Elizabeth Martin, "Organizing for a Change: The DOs and DON'Ts of Fighting Pesticides," Race, Poverty, and the Environment 2 (Spring 1991): 4.

46. Robert D. Bullard, Dumping in Dixie: Race, Class, and Environmental Quality (Boulder, Colo., 1990), p. 45. Among the concluding "action strategies" recommended by Bullard, the leading sociological analyst of and advocate for the amelioration of environmental racism, is 
with a common sense of place and social identity disrupted by toxic menace. The image of the holistic settlement can, however, be quite ductile; it can be extended to comprise not only historically self-identified entities like Alsen, Louisiana ("a rural community of black landowners [that evolved into] its present status as a stable, working-class suburban [98.9 percent black] enclave"), but also statistical districts like zip code 90058 in South Central Los Angeles. ${ }^{47}$ ("The neighborhood is a haven for nonresidential activities. More than eighteen industrial firms in 1989 discharged more than 33 million pounds of waste chemicals in this ZIP code." $)^{48}$

In short, toxic discourse may invoke a sense of place to call a localized collectivity into being or, if it is already self-consciously there, to raise it to a higher degree of self-consciousness. This politics of elasticity, however, is not at all inconsistent with the sociology of place itself in the contemporary world. As one social geographer puts it, "place refers to the process of social structuration," not to some reified abstraction, a process furthermore that "cannot be understood without reference to the "outside forces' that help define those places." ${ }^{49}$ In toxic discourse, the forces are of course the invader whose unwanted attention has marked this locale off as worthy of remark, the EJ activist-facilitator, and the reader whose concern is drawn to this locale as a marked territory. Contestation of what counts as a place is to be expected, then.

The more toxic discourse focuses on specific cases, the more readily toxic discourse montages into gothic. ${ }^{50}$ When Carson goes to the supermarket, her attention is riveted by the spectacle of "substances of far greater death-dealing power than the medicinal drug for which [one] may be required to sign a 'poison book' in the pharmacy next door. ... Within easy reach of a child's exploring hand" are fragile glass containers filled with convulsion-inducing chemicals. "These hazards follow the purchaser right into his home" in the form of such products as kitchen shelf paper "impregnated with insecticide, not merely on one but on both sides" (SS, pp. 157, 158). Today's how-to-do-it detoxification guides are full of similar cautionary tales like the case of "self-employed suburban

the recommendation to "institute 'adopt-a-community' programs at historically black colleges and universities ... around environmental justice and resource allocation areastargeting minority communities threatened by toxics" (p. 115).

47. Ibid., p. 65 ;

48. Bullard, "Anatomy of Environmental Racism," in Toxic Struggles, p. 30, elaborating on an article from the San Francisco Examiner describing zip code 90058 as "the 'dirtiest' in the state"; italics mine.

49. John A. Agnew, Place and Politics: The Geographical Mediation of State and Society (Boston, 1987), p. 36 .

50. In U.S. literary history, linkage of gothic representation with public health issues begins with the first novelist of strong claims to major importance, Charles Brockden Brown, in Arthur Mervyn (1798), which includes a grisly portrayal of Philadelphia's 1793 yellow fever epidemic. 
engineer" Eugene Beeman, who "tightened his house to make it more energy efficient" and died of carbon monoxide poisoning as a result, or that of Dana Shrier, who traces her recurring "heart palpitations and joint pains" to "pesticide residues" in her mattress. ${ }^{51}$

Toxic discourse's gothicism is most lurid when the victim has no choice, as Beeman and Shrier did, at least in principle. Five-year-old Anttwon Suggs's story opens a Los Angeles Times investigative article on the worldwide increase of asthma among children and especially inner-city African Americans. Overcome by a seizure at school, Anttwon gasped for breath and begged his teacher for help, "but she scolded him for misbehaving before she realized he wasn't clowning around." Taken, too late, to the school nurse's office, "panic began to set in" and his "eyes bulged with terror as he fought to draw oxygen through his clogged airways." His hastily summoned mother, "fighting back her own hysteria," tried vainly "to calm him as her only son drew his final breath and died,"52 trapped in the chambers of the school-dungeon. What this report finds especially shocking is that the incident seems to typify the plight of a whole class of juvenile victims whose life narratives unscroll in an endless series of tragedies in the community, the neighborhood, and the workplace.

As with our previous topoi, here too the precursor forms predate early industrialization. Surveying antebellum exposés of "the lower depths" of New York City, Eric Homberger notes their reliance on "the Virgilian mode": "the guided tour of the underworld" slums that allegorizes them in classico-biblical terms as "the home of lost souls" so as to instill shock and compassion in insouciant middle-class readers. ${ }^{53} \mathrm{Her}$ man Melville carried the Virgilian mode to the mill towns of New England ("you stand as within a Dantean gateway" at the threshold of the ravine leading to the "Tartarus of Maids"), ${ }^{54}$ and Rebecca Harding Davis carried it to the industrial cities in the hinterland ("take no heed to your clean clothes, and come right down with me,- - here, into the thickest of the fog and mud and foul effluvia"). ${ }^{55}$ It remained a staple of journalistic exposés like Jacob Riis's How the Other Half Lives (1890) and Jack London's The People of the Abyss (1903), of novelistic equivalents like Dickens's Bleak

51. Lynn Lawson, Staying Well in a Toxic World: Understanding Environmental Illness, Multiple Chemical Sensitivities, Chemical Injuries, and Sick Building Syndrome (Chicago, 1993), pp. 82,151 .

52. Marla Cone, "Leaving a Generation Gasping for Breath," Los Angeles Times, 27 Oct. 1996, p. A28.

53. Eric Homberger, Scenes from the Life of a City: Corruption and Conscience in Old New York (New Haven, Conn., 1994), pp. 30, 13.

54. Melville, "The Paradise of Bachelors and the Tartarus of Maids," Piazza Tales and Other Prose Pieces, 1839-1860, ed. Harrison Hayford et al. (Evanston, Ill., 1987), p. 324.

55. Rebecca Harding Davis, "Life in the Iron Mills," in The Norton Anthology of American Literature, 4th ed., ed. Nina Baym et al., 2 vols. (New York, 1994), 1:2488. 
House (1853) and Hard Times (1854) and Sinclair's The Jungle, as well as of the measured analysis of early modern investigative research, such as the work of Jane Addams's protégée Alice Hamilton, the foremother of industrial toxicology. In her autobiography, Hamilton recalls a bleak January visit to a lead-smelting operation in Joplin, Missouri,

the very dreariest, most hopeless community I had ever seen ... around the village not a tree, only ... the refuse from the concentrating mills which formed huge pyramids of ground rock and wide stretches of fine sand as far as the eye could see. As I looked there came to mind that Old Testament verse: "And the heaven that is over thy head shall be brass, and the earth that is under thee shall be iron." 56

Here we also see the Virgilian mode's potential double bind: advocating social regeneration by reinscribing the polarization of saved versus damned, the guide being so much wiser, so much more like us, than the hapless, hardly human victims. Sometimes the condescension is quite deliberate. In the macho adventurer London and in the photographervoyeur Riis, pity can lapse abruptly into contempt. Dickens's humanitarianism and his conviction that the fate of the world's Lady Dedlocks is indissolubly linked to that of the world's starving paupers, keep him from this; yet neither Dickens nor Sinclair will abdicate narrative omniscience, any more than Hamilton will question that the best way to diagnose and remediate the environmental problems in the workplace is cooperation between experts and managers.

Contemporary toxic discourse inherits this ambiguous legacy. Carson relies at every turn on scientific authority. But in Silent Spring the terms of the author-audience relation to the scenes depicted have changed, both parties now being potential if not actual denizens of the toxic Inferno. In contemporary toxic discourse, furthermore, victims are permitted to reverse roles and claim authority. EJ movement journals like Race, Poverty, and the Environment and $E$ contain extensive grassroots affidavits from community representatives along with the corroborating testimony of activist-investigators and scholar-consultants. The insider affidavits make central those moments in Virgilian gothic when-in the spirit of the Inferno itself-the sufferer briefly achieves agency by becoming the guide's guide.

Altogether, the four formations, both in their cultural embeddedness and in their contemporary transposition, promote a unifying culture of toxicity notwithstanding the increasing recognition of the importance of such marks of social difference as race, gender, and class in determining what groups get subjected to what degree of risk. Carson's adoption by 
the EJ movement as harbinger, prophet, and foremother is exemplary in that Silent Spring's controlled analytical-satiric tone and documentary circumspection mark it as directed toward a well-educated, middle-class, sub/urban citizenry (originally it was serialized in The New Yorker) by a person of the same background; yet it is also a book whose passionate concern for the possibility of global victimization and whose postpublication ordeal as a vindicated and triumphant martyr of industry-led attack (the pathos of which was intensified by the author's own death from cancer soon after) reidentifies it as a work of "universal" scope speaking from, as well as to and for, the positions of toxic victims in every place or social niche..$^{57}$

So much by way of anatomy and genealogy. Now let us turn to some broader implications of this Virgilian tour for the understanding of the work of environmental representation, both as textual construct and as critical intervention. One implication, clearly, is that toxic discourse calls for a way of imagining physical environments that fuses a social constructivist with an environmental restorationist perspective. Against ecocriticism's preferred model of an "ecological holism" to which "acts of imagination" have the capacity to (re)connect us, ${ }^{58}$ toxic discourse holds that belief in the availability of such a holism by such means is chimerical and socially divisive. Yet it recognizes both the strategic value and the benefit to human and planetary welfare of the ideal of a purified physical environment as a collective goal, thereby recognizing the physical environment's nonreducibility to ideological artifact or socioeconomic counter. Its impetus is both to reinforce the deromanticization of nature and to urge its expansion as an operative category.

On the one hand, physical nature's cultural importance, indeed nature's nature itself, ceases to be located in its promise as past, present, or future sanctuary but rather in its role as humanity's codependent and coconspirator in coping with what Bill McKibben has called the "end of nature," that is, the fact/awareness that the nature one engages must now inescapably be-if indeed it has not always already in some sense beennot pristine but "second" (that is, inevitably somewhat modified) nature or (in Derek Jarman's less ambiguous phrase) "modern nature": involving

57. The best biographical study of Carson's career, placing special emphasis on her later years and Silent Spring, is still her publisher's memoir, Paul Brooks, The House of Life: Rachel Carson at Work (Boston, 1972). For a chronicle of the controversy that the book provoked in the 1960s, see Frank Graham, Jr., Since "Silent Spring" (Boston, 1970).

58. Karl Kroeber, Ecological Literary Criticism: Romantic Imagining and the Biology of the Mind (New York, 1994), pp. 32, 21. 
some sort of mutual constitution of the natural and the social. ${ }^{59}$ However one might wish otherwise, the modern nature that toxic discourse recognizes as the physical environment humans actually inhabit is not a holistic spiritual or biotic economy but a network or networks within which, on the one hand, humans are biotically imbricated (like it or not) and, on the other hand, nature figures as modified (like it or not) by techne. This view is neither preservationist, given its recognition of the impact of human powers and the legitimacy of human needs, nor conservationist, since its goal is not resource management so much as effective symbiosis with the physical environment.

On the other hand, and by the same token, the boundaries of nature or environmental discourse now become much more elastic than formerly conceived. Alexander Wilson declares during the course of a provocative dissection of North American settler culture's dominant assumptions about landscape that "the contemporary ideology of city and country as discrete and exclusive land forms has been destructive" both in its socioeconomic compartmentalization and its impoverishment of the sense of the ecological status and potential of both domains. The resultant stereotypes inhibit recognizing the country's status as a site of production and the city's need for greater ecological self-sufficiency ${ }^{60} \mathrm{~A}$ similar point could be made about the traditional linkage in literary studies of environmental consciousness to outback genres like wilderness romance and "nature writing" rather than with naturalist fiction of the city or urban journalism, even in the face of cases of many border-crossing, environmentally responsive writers like Walt Whitman, Stephen Crane, Jack London, Jean Toomer, and John Steinbeck whose multicontextual range exposes the speciousness of such compartmentalization. Once one begins to entertain toxic discourse as a possible prototype of environmental imagining, however, the compartments begin to break down, so that it makes sense to consider Richard Wright and Charles Dickens as writers with a sense of environmental "ecology" as keen as that of "ruralizing" counterparts like Zora Neale Hurston or Thomas Hardy.

Nowhere is this blurring of standard genre classifications more striking than in contemporary works of "nature writing" written under the

59. See Bill McKibben, The End of Nature (New York, 1989); Michael Pollan, Second Nature: A Gardener's Education (New York, 1991); and Derek Jarman, Modern Nature: The Journals of Derek Jarman (London, 1991). McKibben, worried especially about global warming, sees the end of nature in apocalyptic terms as a global tragedy, psychologically and culturally impoverishing as well as biotically threatening. Despite the fact that it records the experience of imminent death from AIDS, in Jarman's journal the human-(modern) nature encounter offers much more significant and uplifting possibilities, partly because its expectations of what that encounter with physical nature ought to mean are less ambitious to begin with.

60. See Alexander Wilson, The Culture of Nature: North American Landscape from Disney to the Exxon "Valdez" (Cambridge, 1992), p. 203. 
pressure of toxic discourse, like Terry Tempest Williams's Refuge ${ }^{61}$ Refuge unfolds a double plot of a Utah wildlife sanctuary endangered by a rise in the Great Salt Lake and of the women in Williams's family permanently maimed by cancer that might have been caused by downwind fallout from a decade of above-ground nuclear tests at Yucca Flats, Nevada. The book culminates with the narrator's realization that her family might have been put at risk unawares by accidentally being too near a particularly dirty explosion in the early $1950 \mathrm{~s}^{62}$

The two fields of Williams's vision-wildlife and family illness-pull with and against each other by turns. Wilderness is both antidote to illness and escape from facing it; the deaths of mother and grandmother are both natural processes and profoundly unnatural; and the way the narrator splits attention between these foci is both therapeutic and symptomatic of the fitful grasp that she and her culture have of the relation between their mind-bodies and the environmental envelope that contains them. This allows Williams both to acknowledge and to resist the desire to cordon off the natural from the social-the hazard of traditional preservationist thinking and the state of innocence from which ecopopulist leaders like Lois Gibbs had to awaken before they could understand what was happening to their communities. Refuge becomes metacommentary on pastoralism's wish-fulfilling turn. Like Carson before her, Williams perceives that human communities and physical environment both stand to gain when the impact upon reading audiences of a represented awakening to what is most troublesome about that interdependence begins to approximate the startled awakening of victims of actual contaminated communities themselves, for whom "environment becomes much more important to their understanding of life than it was previously likely to

61. In contemporary fiction, Jane Smiley's $A$ Thousand Acres (1991) does the same with the agrarian novel (for example, Willa Cather's O Pioneers! [1913]), portraying a family poisoned (in all senses) by its success at high-tech farming.

62. Terry Tempest Williams, Refuge: An Unnatural History of Family and Place (New York, 1991 ) is actually one of a number of recent works by various enterprising writers and artists about law-abiding, God-fearing Mormon villages in southern Utah ravaged by what looks to have been a long history of faulty planning, botched execution, public relations duplicity, bureaucratic intimidation, and government cover-up. See also John G. Fuller, The Day We Bombed Utah (New York, 1984); Philip L. Fradkin, Fallout: An American Nuclear Tragedy (Tucson, Az., 1989); and Carole Gallagher, American Ground Zero: The Secret Nuclear War (Cambridge, Mass., 1993). These works, all cited by Williams herself, are journalistic works (photojournalism in Gallagher's case) strongly judgmental and critical of the AEC. For the other side, see Barton C. Hacker, Elements of Controversy: The Atomic Energy Commission and Radiation Safety in Nuclear Weapons Testing, 1947-1974 (Berkeley, 1994), a work commissioned by a Department of Energy Nevada Operations prime contractor (Reynolds Electrical and Engineering Company). Note that although Hacker absolves officials of conscious wrongdoing, he also concludes that the AEC's "carefully crafted press releases" "sometimes erred" and "rarely if ever revealed all" (p. 278). 
be," and this in turn tends to undermine "their belief in [human] dominion over earth that characterizes the view of Western civilization."63

The emphasis that Refuge places upon the inextricable imbrication of outback with metropolis is not only a significant swerve from the circumscription of focus in standard nature writing but also a reconception of that tradition in the sense that it points to an interdependence that was always there to start with but whose implications were never fully acknowledged. The most canonical of such works in American literary history, Thoreau's Walden, acknowledges frankly at start and close that the writer not only once was but is now "a sojourner in civilized life again"; ${ }^{64}$ and it is from that uneasy hybrid perspective that the ecocentric turn in the book is to be read, as well as the relationship between it and Thoreau's political theory (of civil disobedience), which evolved as the book-which indeed makes reference to his incarceration-was in progress.

Refuge both levels charges and carefully avoids claiming more than it can prove about the source(s) of the family's illnesses. This produces a certain tortuousness in the book that points to a second set of critical issues raised by the discourse of toxicity.

Earlier we noted the importance of moral melodrama to toxic discourse, as well as the totalizing rhetoric with which it sets forth claims of environmental poisoning. Reading it, as Martha Nussbaum writes of the experience of reading Dickens's Hard Times, readers feel "constituted by the novel as judges of a certain sort." Nussbaum readily accepts the legitimacy of this role, convinced that the ability to imagine empathetically the lives of socially marginal people as novelists like Dickens do is an important asset in the crafting of coherent, perceptive legal argument. But what about the question of evidence? Although "the literary judge" may indeed be more apt to wish to read a case "in its full historical and social context," he or she must also reckon with the phenomenon of narratorial bias in the documentary-analytical texture of fiction like Hard Times, not to mention in the oxymoronic multigenre of nonfiction. ${ }^{65}$ Toxic discourse raises this question with unusual poignancy.

Although what has been said above is meant to imply that toxic discourse rests on anxieties about environmental poisoning for which there is copious historical evidence, it is plainly a discourse of allegation rather than of proof. Its moralism and intensity proceeds in good part precisely from the awareness that its charges have not yet been proven, at least to the satisfaction of the requisite authorities. During two decades of ecopop-

63. Edelstein, Contaminated Communities, p. 57.

64. Henry D. Thoreau, Walden, ed. J. Lyndon Shanley (Princeton, N.J., 1971), p. 3.

65. Martha Nussbaum, Poetic Justice: The Literary Imagination and the Public (Boston, 1995), pp. 83, 115. The case of reference here is Bowers v. Hardwick (1986), in which the U.S. Supreme Court upheld a Georgia antisodomy law against the claim of privacy rights. 
ulism, "almost every claim that a risk is present, almost every attribution of cause, [has been] vigorously contested" $(E c$, p. 31$){ }^{66}$ It is notoriously hard to demonstrate environmental causation of illness, given the limitation of preexisting research bases, not to mention the multiplicity of possible causal agents. The generation of conclusive scientific data and accompanying regulatory codes is a lengthy and haphazard process; ${ }^{67}$ and, in any case, as the father of contemporary risk assessment theory acknowledges, "science cannot prove safety, only the degree of existing harm. Thus, new technologies cannot be proven safe before use." 68 The problem of reaching even approximate certitude is compounded by the predictable reluctance of allegedly responsible parties to concede error and by the cumbersomeness of the process by which error is legally determined. At Love Canal, "officials [never] agreed that there was a health problem" other than possible hazard to pregnant women and small children $(L C$, p. 170). ${ }^{69} \mathrm{~A}$ suit by families within a leukemia cluster in Woburn, Massachusetts, against W. R. Grace for chemical dumping was settled out of court in 1986 for $\$ 8$ million after the judge ordered the case retried on the grounds that the jury, which had voted to convict, did not understand the hydrological evidence. ${ }^{70}$

This climate of scientific and legal complexity calls toxic discourse into question even in advance 'of its utterance yet, at the same time, argues for both its social importance and its ethical legitimacy. On the one hand, the deliberate pace and methodological probabilism of scientific and legal procedures run counter to the precipitous and absolutist thrust of toxic discourse, leaving self-identified victims of environmental illness

66. Some of the attendant social, scientific, and legal problems are explored from a perspective different from my own in Phantom Risk: Scientific Inference and the Law, ed. Kenneth R. Foster, David E. Bernstein, and Peter W. Huber (Cambridge, Mass., 1993).

67. See David V. Bates, Environmental Health Risks and Public Policy: Decision Making in Free Societies (Seattle, 1994), p. 90.

68. Chauncey Starr, "Risk Management, Assessment, and Acceptability," Risk Analysis 5, no. 2 (1985): 99.

69. This is corroborated by Mazur, Love Canal, which tends to emphasize homeowner overreaction (particularly among residents beyond the "first" or central ring) and the flaws in the "scientific" studies that purported to establish the likelihood of environmentally induced medical problems. Mazur does not deny the possibility of the latter, by any means, but confines himself to the available epidemiological evidence.

70. See Phil Brown and Edwin J. Mikkelsen, No Safe Place: Toxic Waste, Leukemia, and Community Action (Berkeley, 1990), p. 30. Jonathan Harr's A Civil Action (New York, 1995), a narrative reconstruction of the Woburn case, emphasizes the plaintiff's counsel's imminent fear of bankruptcy, judicial strictness, and tenuousness of the evidence as the reasons for the prosecution's acceptance of the out-of-court settlement rather than the confusion of the jury or the ordering of the new trial, which in Harr's account was nothing more than a public gesture orchestrated at the judge's request as part of the settlement arrangement. Whatever may have been the exact chain of events, Harr, like Brown and Mikkelsen, makes amply clear throughout his book the formidable technical and practical difficulties of gathering and interpreting the relevant evidence. 
oscillating between implacable outrage and miserable uncertainty. Williams, for instance, concedes that "I cannot prove that my mother ... or my grandmothers ..., along with my aunts developed cancer from nuclear fallout in Utah. But I can't prove they didn't." 11 This sense of frustrated indeterminacy pushes her toward a strategy of hesitant but persistent insinuation. The same holds to an even greater degree for the Hollywood film Safe, which is about an upscale woman from the San Fernando valley with a burgeoning array of what she's increasingly convinced are environmentally induced allergic symptoms dating back to childhood asthma; but the patriarchal family doctor finds nothing wrong with her and prescribes an equally patriarchal psychiatrist. Does her final retreat to a hermetic, igloo-like "safe house" at an exclusive holistic health ranch in the hills above Albuquerque result from physiological vulnerabilities or from social dysfunction? The film insinuates the former by making it the ostensible catalyst, but the film equivocates by suggesting the alternative possibility throughout the narrative.

Yet the very climate of scientific and legal probabilism that makes Williams cautious and makes Safe end ambiguously might seem to demand a rhetoric of unequivocal assertion as counterforce. As Lois Gibbs declared, "I don't see why you need scientific certainty when people's lives and health are at stake" ( $L C$, p. 69). Likewise, the most thorough study of ecopopulism to date defends the reasonableness of flat refusal to accept indeterminate degrees of environmental risk, at least in such cases as hazardous waste deposits; for "the claim that the risks of proper disposal or treatment are known rests on the assumption that permitted facilities operate as advertised, a claim that is not credible in light of the EPA's enforcement record. Given the current state of knowledge and the current state of regulatory enforcement, there is no way to validate claims that the risks are known to be minor or acceptable." On the contrary, "experts have shown that even the best-designed landfills are certain to fail" ( $E c$, pp. 148, 149). Add to this the risk assessment community's concession that "public acceptance of any risk is more dependent on public confidence in risk management than on the quantitative estimates of risk consequences, probabilities, and magnitudes,"72 and toxic discourse starts to look not only conceptually justifiable but socially indispensable, particularly when the technology in question can be expected to produce what organizational sociologist Charles Perrow calls "normal accidents"; that is, the system's "interactive complexity" and "tight coupling" of sequenced processes are such that

71. Williams, Refuge, p. 286.

72. Starr, "Risk Management, Assessment, and Acceptability," p. 98. For further discussion of the significance of perceived as opposed to "real" risk, see Raphael G. Kasper, "Perceptions of Risk and Their Effects on Decision Making," and Paul Slovic, Baruch Fischhoff, and Sarah Lichtenstein, "Facts and Fears: Understanding Perceived Risk," in Societal Risk Assessment: Hov' Safe Is Safe Enough? ed. Richard C. Schwing and Walter A. Albers, Jr. (New York, 1980), pp. 71-80, 181-214. 
accidents have to be expected in the nature of the case. ${ }^{73}$ The situation seems all the more worrisome if one accepts the dictum that "no system can maintain itself by means of a point-for-point correlation with its environment, i.e., can summon enough 'requisite variety' to match its environment." ${ }^{74}$

Thus the shrill apocalypticism of antitoxic advocacy may be defensible not only as a recourse for the disempowered but also as a need made specifically by the culture of expertise of which the academy is a part and which intellectuals propagate. The culture that sustains the procedural rigor that perpetuates the finding of indeterminacy stands accused de facto of perpetually deferring the obligation to $d o$ something beyond critical interrogation of the problem. Meanwhile, the more ambiguous representations offered by texts like Refuge and Safe acknowledge the force of toxic anxiety, thus helping ensure that it stays on the public agenda, notwithstanding their self-conflicted wonderment as to whether anxiety might be paranoia.

They thereby also suggest, however, the liability of discourse becoming its own sanctuary. Activists have sometimes worried about this. With the hindsight of two decades of committed social work, Jane Addams berated herself "that in my first view of the horror of East London I should have recalled [Thomas] De Quincey's literary description" in "The English Mail Coach" of a case of absorption in literary meditation rendering the persona incapable of preventing an accident in "real life." Although the recollection of this literary simulacrum of paralysis seems to have been precisely what jolted Addams from armchair malaise, she took it as a form of insular decadence that her mind was even fleetingly held captive by intertextuality "at the very moment of looking down from the top of the omnibus" upon real poverty. ${ }^{75}$ Though her postpuritan scrupulousness may have been overnice, she was not wrong to worry about this form of entrapment. Toxic discourse may repress, fail to fulfill, or swerve away from itself according to the drag of other formations with which it cross-pollinates. In the powerful middle section of Don DeLillo's novel White Noise (1985), for example, the protagonist's life becomes transformed when he is exposed to a lethal dose of what local authorities eu-

73. Charles Perrow, Normal Accidents: Living with High-Risk Technologies (New York, 1984), p. 4. After a lengthy critique of the assumptions and practices of the discipline of risk assessment, Perrow concludes that "a technology that raises even unreasonable, mistaken fears is to be avoided because unreasonable fears are nevertheless real fears. A technology that produces confusion, deception, uncertainty, and incomprehensible events (as the [Three Mile Island] crisis did) is to be avoided. . . A worker's death is not the only measure of dread; the absence of death is not the only criterion of social benefit" (p. 323).

74. Niklas Luhmann, Ecological Communication, trans. John Bednarz, Jr. (Chicago, 1989), p. 11. In his persona as systems theorist, interestingly, Luhmann himself seems to regard this prospect with complete equanimity.

75. Jane Addams, Twenty Years at Hull-House, with Autobiographical Notes, ed. James Hurt (1910; Urbana, Ill., 1990), pp. 43, 41. 
phemistically call "the airborne toxic event," a spectacular accident that traumatizes the community. The incident destroys the complacency with which he initially brushes off the explosion, assuring his family that "'these things happen to poor people who live in exposed areas. Society is set up in such a way that it's the poor and the uneducated who suffer the main impact of natural and man-made disasters." 76 For a while the novel seems to have crystallized around this awakening. But in the long run ecocatastrophe is invoked only to be reduced to the status of catalyst for the unfolding of the deeply banal inner life of this professor of "Hitler Studies" at a lackluster hinterland university, and the irony of his and his wife's chronic, narcissistic death-obsessions, which are longstanding and only fortuitously linked to the precipitating event. The traditional protocols of protagonist-centered fiction prevent ecodiscourse from becoming much more than a plot function and symbolic character marker, significant in the long run chiefly as a symbolic reminiscence of the Holocaust that Professor Gladney's way of defining his field has until now repressed.

The turn toward recontainment of toxic event as symbol here raises the same question asked by Susan Sontag in another context: Is there something inherently problematic about converting pestilence into metaphor? ${ }^{77}$ My metaphor elides, derealizes, somebody else's pain. DeLillo starts to look eerily like the rich suburbanite in Safe, moving about from one place of privilege to another. Her awakening to toxicity has the effect of sealing her off more tightly from ordinary people than she was in her villa just as rich nuclear alarmists of the 1950s built opulent bomb shelters that they stocked with gourmet provender. Is White Noise's recontainment of a toxic event (not to mention the Holocaust) within the more familiar and comfortable frame of Professor Gladney's postexistentialist psychodrama comparable to this? ${ }^{78}$

For at least two reasons, one might not want to go so far. First, even relegation to subsidiary metaphor status is something rather than nothing. Once imaged, the event cannot be retracted. There is considerable warrant for believing that even dead metaphors (for example, a black-

76. Don DeLillo, White Noise (New York, 1985), pp. 117, 114.

77. See Susan Sontag, Illness as Metaphor (New York, 1978) and AIDS and Its Metaphors (New York, 1989). Ironically, considering the present subject, one of Sontag's targets is the assumption of environmental causation of illness, which she opposes both questionably as bad science and more cogently as a possible slippery slope toward the depersonalization of the sufferer into a symptom of cultural pathology (for example, this or that despised social group as a "cancer" on society). Pressing in this direction, however, keeps her analysis from anticipating what is potentially problematic about the opposite pitfall, to which protagonistcentered novels are generically susceptible: privileging individual suffering to the elision of contextual ground.

78. The ethics of representation in post-Carson toxic discourse itself might of course be questioned on this same count, insofar as the Holocaust is appropriated metaphorically in such formulations as "environmental holocaust." 
and-white situation) shape or at least reinforce cultural values. ${ }^{79}$ Second, metaphorization in this instance is probably better understood as partial realization than as a desire to repress. The case is hardly equivalent to the rhetoric of calculated military euphemization analyzed by Elaine Scarry. ${ }^{80}$ In the mid-1980s, toxicity was still only starting to assert itself as a personal reality for the mythical average American. Love Canal and Superfund were but a few years old. Whatever his or her other motives, a novelist of middle-class manners would have had to contend with the embedded sense of distance between the stuff of headline news about toxic events and the predictable but only apparent stability and safety of bourgeois life in middle-class American towns and suburbs.

The metaphorization of waste is an instructive analogue case. For Wallace Stevens, a dump was a symbolic location, merely: a repository of used-up images. Thomas Pynchon made W.A.S.T.E. a symbol of another sort: of the subversiveness of the Tristero. ${ }^{81}$ Even for a creative writer of much more ecocentric persuasion, the impulse still runs strong to recycle waste as metaphor, as in A. R. Ammons's 1993 National Book Awardwinning poem Garbage. "Garbage has to be the poem of our time," the speaker insists: but why? Because "garbage is spiritual," a symbol for the age: a multivalent symbol, indeed, connoting among other things Stevens's old metaphor of shopworn creativity. Much more resolutely than Stevens, Ammons remains continuously aware of garbage's materiality, of its toxification of the planet, and of the human body in its terminal states of materiality. The title image remains as much a threshold, a stimulus to poetic play, as a socioenvironmental referent. The poem engages environmental concerns, but only as one among many concerns. In the process, though, it wryly ironizes its own bystander status ("I don't know anything much about garbage / dumps: I mean, I've never climbed one”); it strives to "ecologize" Stevens's trope by insisting on garbage's reuse (poetry "reaches down into the dead pit / and cool oil of stale recognition and words and / brings up hauls of stringy gook which it arrays / with light and strings with shiny syllables"); and its seriocomic metamorphics alter-

79. The strongest version of this argument is set forth in George Lakoff and Mark Johnson, Metaphors We Live By (Chicago, 1980). Naomi Quinn argues instead that "metaphors, far from constituting understanding, are ordinarily selected to fit a preexisting and culturally shared model," though "they may well help the reasoner to follow out entailments of the preexisting cultural model" (Naomi Quinn, "The Cultural Basis of Metaphor," Beyond Metaphor: The Theory of Tropes in Anthropology, ed. James W. Fernandez [Stanford, Calif., 1991], p. 60).

80. See Elaine Scarry, The Body in Pain: The Making and Unmaking of the World (New York, 1985), esp. pp. 60-91.

81. See Wallace Stevens, "The Man on the Dump," The Palm at the End of the Mind: Selected Poems and Plays, ed. Holly Stevens (New York, 1972), pp. 163-64, and Thomas Pynchon, The Crying of Lot 49 (1966). Michael Harper's "Landfill" manages a more literal dump, but with strong symbolic overtones; see Michael S. Harper, "Landfill," Images of Kin: New and Selected Poems (Urbana, Ill., 1977), p. 41. 
nates with environmental jeremiad ("poetry to no purpose! all this garbage! all / these words: we may replace our mountains with / trash: leachments may be our creeks flowing / from the bottoms of corruption"). ${ }^{82}$ If toxification is not consistently the central subject, it is central to the poem's cultural landscape, and an energizing concern. Metaphorical fugacity may bespeak a certain amount of uneasiness about confronting toxicity, but by the same token it marks toxicity as an emergent literary focus. Besides, would anyone want to insist that even every environmentally responsive creative writer of our time commit to writing elaborations of Silent Spring? Carson herself didn't.

Meanwhile, the sociological evidence of the emergence of toxicity as a widely shared paradigm of cultural self-identification and of toxic discourse as a commensurately influential force continues to accumulate. The evidence suggests that the sheer eloquence-the affect-of testimony of ordinary citizens' anxiety about environmental degradation can have substantial influence on public policy, especially when the media are watching. ${ }^{83}$ Against the parsimony and procedural conservatism of legislative and regulatory bodies, and their susceptibility to lobbying by vested interests, not just individuals but communities have begun to develop what some environmental anthropologists call "disaster subcultures" (whereby community ethos and social rituals get shaped by the recollection and/or anticipation of environmental disaster) ${ }^{84}$ More and more it may become second nature to everyone's environmental imagination to visualize humanity in relation to environment, not as solitary escapees or consumers, but as collectivities with no alternative but to cooperate in acknowledgement of their necessary, like-it-or-not interdependence.

82. A. R. Ammons, Garbage (New York, 1993), pp. 18, 35, 108, 75. On Ammons's responsiveness to environmental issues, see for example Jon Gertner, "A Walk with A. R. Ammons," Audubon 98 (Sept.-Oct. 1996): 74-82.

83. In addition to Gottlieb and Clarke, see, for example, Waddell, "Saving the Great Lakes." One of the commissioners of the International Joint Commission on water quality told Waddell that "'to see the people directly, in front of you, that were directly affected, there was an emotional impact ... that had a tremendous impact on me"' (p. 154). Folk eloquence in the context of organization and argument must often be credited with carrying power even in the context of eventual defeat, as when citizen opposition fended off a proposed Alberta-Pacific pulp mill at two levels of appeal before reversal by provincial government manipulation; see Mary Richardson, Joan Sherman, and Michael Gismondi, Winning Back the Words: Confronting Experts in an Environmental Public Hearing (Toronto, 1993).

84. John T. Omohundro, "From Oil Slick to Greasepaint: Theatre's Role in a Community's Response to Pollution Events," Communities at Risk, p. 165. 